\title{
Bering Glacier and Bagley Ice Valley surge 2011: crevasse classification as an approach to map deformation stages and surge progression
}

\author{
Ute C. HERZFELD, ${ }^{1,2,3}$ Brian McDONALD, ${ }^{1,2}$ Alexander WELTMAN ${ }^{1,4}$ \\ ${ }^{1}$ Department of Electrical, Computer and Energy Engineering, University of Colorado, Boulder, CO, USA \\ E-mail: ute.herzfeld@colorado.edu \\ ${ }^{2}$ Cooperative Institute for Research in Environmental Sciences, University of Colorado, Boulder, CO, USA \\ ${ }^{3}$ Department of Applied Mathematics, University of Colorado, Boulder, CO, USA \\ ${ }^{4}$ Department of Computer Sciences, University of Colorado, Boulder, CO, USA
}

\begin{abstract}
The dynamics of a surge is manifested in the crevasse patterns: literally, deformation state frozen in ice. This basic observation is utilized as the concept of an automated approach to map and analyze deformation stages and progression of surge kinematics. The classification method allows imagery to be used as geophysical data and is applied to aerial observations (photographic and video imagery, GPS data) collected in September 2011 during the surge of the Bering Glacier-Bagley Ice Valley system, Alaska, USA. As the third dimension that complements two-dimensional imagery, icesurface elevation is observed using aerial laser altimetry. The classification method builds on concepts from signal processing, geostatistical data analysis and neural networks. Steps include calculation of generalized directional vario functions from image data and composition into feature vectors. The vario function operates as an information filter that retains spatial characteristics at an intermediate scale that captures crevasse spacing, anisotropy and other generalized roughness properties. Association of feature vectors to crevasse classes and hence deformation types employs a connectionist algorithm. In general, the connectionist-geostatistical classification allows the mapping of kinematic changes in crevassed glaciers.
\end{abstract}

Dedicated to the memory of Austin Post

\section{INTRODUCTION: THE PROBLEM OF UNDERSTANDING SURGE PROGRESSION IN A LARGE, COMPLEX GLACIER SYSTEM}

Understanding acceleration in glaciers and fast-glacier movement is essential to understanding changes in the cryosphere. Glacier surging is one of three types of fast glacier flow (Clarke, 1987) - ice streams, surging, and tidewater glaciers - and the one that has been least researched. This paper is dedicated to designing an approach that facilitates objective analysis and parameterization of surge progression in a large and complex glacier system, using observations of the current surge of the Bering-Bagley glacier system, Alaska, USA.

A surge is a catastrophic dynamic event, during which a glacier accelerates to 10-100 times or more of its normal velocity and advances rapidly. Heavy crevassing indicative of sudden deformation, horizontal and vertical displacement of ice and sudden changes in the glacial hydrologic system are characteristics of a surge. The contemporary state of knowledge on the surge process was summarized by Meier and Post (1969), Raymond (1987) and Harrison and Post (2003), who each concluded that the physics of the surge process were still not understood. It is known that a surge glacier builds up ice in a reservoir area during the long, quiescent phase of the surge, and this ice is then rapidly released during the surge phase. The kinematic wave associated with the surge travels up-glacier and downglacier. Surges occur in several stages (Herzfeld and Mayer, 1997; Herzfeld, 1998). In recent studies, the effects of glacier geometry, climate and setting, of basal morphology and composition of the bed, or rather, susceptibility of the bed material to deformation, and of englacial water distribution have been investigated in three respects: as factors that may explain that a given glacier is a surge-type glacier; as causes of glacier surges; and as triggers of an actual surge (Björnsson and others, 2003; Copland and others, 2003; Fatland and others, 2003; Harrison and Post, 2003; Jiskoot and others, 2003; Lingle and Fatland, 2003; Murray and others, 2003; cf. Bruhn and others, 2010).

Moreover, much of the research on the physics of the surge process is based on a few case studies of mostly smaller glaciers, such as the 1982/83 surge of Variegated Glacier, Alaska (e.g. Kamb and others, 1985; Humphrey and others, 1986; Raymond, 1987), and surges of Trapridge Glacier, Yukon, Canada (Clarke and others, 1984; Flowers and Clarke, 2000, 2002a,b), which are easier to equip with geophysical instrumentation but behave differently than large glaciers. Meier and Post (1969) distinguish three types of surging glaciers: (1) large-sized with high surge velocities, large displacement and large lowering of ice reservoir; (2) large-sized with low surge velocities and small vertical and horizontal ice displacement; and (3) steep and smallsized with small reservoir lowering and ice displacement. The progression of a surge in a large glacier and the characteristic dynamics of each surge phase have not been analyzed systematically.

Bering Glacier, Alaska, is a prototype of a large surgetype glacier of type 1, whose size is comparable to large 


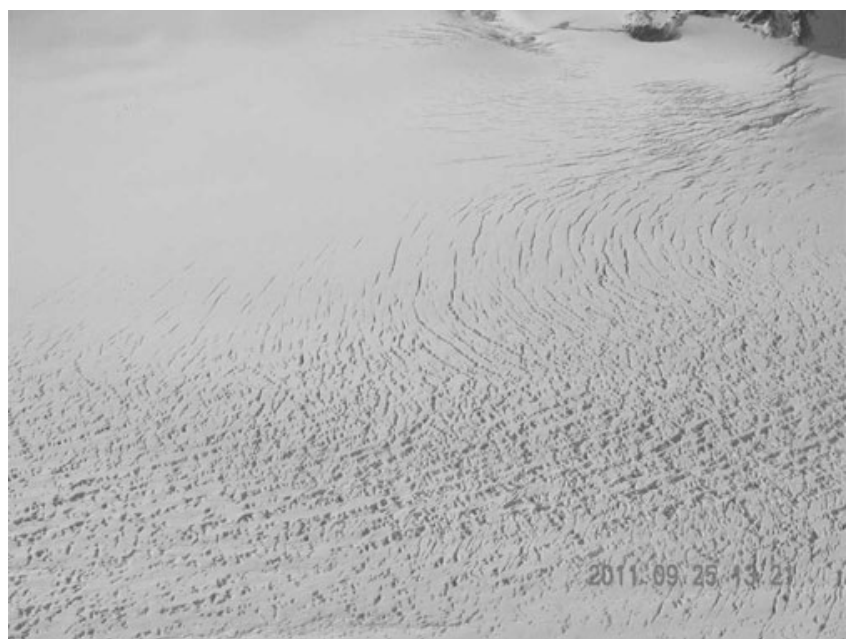

Fig. 1. En-échelon crevasses in Bagley Ice Field; reopening caused by surge progression after recent snowfall, 25 September 2011.

fast-moving ice streams in Greenland, which individually play a role in understanding ice-sheet stability and discharge into the ocean. Bering Glacier is also the largest temperate surge-type glacier on Earth. The surge of Bering Glacier progresses into the Bagley Ice Field (Herzfeld, 1998; Molnia, 2001, 2008; Fatland and others, 2003; Molnia and Post, $2010 a, b)$. Therefore the current surge of the Bering-Bagley system provides a good opportunity to contribute to our understanding of the physics of the surge process in a large and complex glacier system, as well as for research on exemplary processes of ice acceleration in general.

Observing, analyzing and understanding the surge progression in a large glacier requires a different method than measurement of geophysical properties on the ice, because it is not practical to instrument a large glacier. The approach used here is a form of automated spatial analysis of airborne remote-sensing data. The idea is based on the notion that rapid movement of ice manifests itself in crevassing, and that crevasses are associated with deformation provinces in a consistent manner. We establish that this relationship is sufficient to associate surge kinematics/deformation types from imagery collected over a glacier during surge.

Remote-sensing data analysis has been applied in research on the last surge of Bering Glacier (1993-95), resulting in valuable velocity measurements, documentation of front advance and qualitative descriptions of components of the surge process (Fatland and others, 2003; Roush and others, 2003; Molnia and Post, 2010b; Shuchman and others, 2010). For example, Lingle and Fatland (2003) suggest a possible progression qualitatively (in summary, water needs to be stored in a distributed system in the glacier but then the actual surge may be triggered by meteorologic events).

Remote-sensing data analysis of Bering Glacier or any other (large) surge-type glacier has not yet been linked to a physical process model. This requires a discretization and parameterization of kinematic and dynamic processes. In this paper, we describe how automated image analysis and classification can be applied to derive the dynamics of the surge progression during early, mature and late surge stages. The classification yields a set of parameters that capture components of the dynamics of surge progression. The analysis and classification of crevassed ice surfaces from images collected during the current (2011) surge of the
Bering-Bagley glacier system forms a central part of the paper. The vertical component of the surge kinematics can be constrained using analysis of laser altimeter data (Herzfeld and others, 2013).

\section{THE SURGE OF THE BERING-BAGLEY GLACIER SYSTEM IN 2011}

In late spring 2011, Bering Glacier (Fig. 1) started to show definite signs of a surge. Bering Glacier is the largest $\left(\sim 5200 \mathrm{~km}^{2}\right)$ and longest $(\sim 200 \mathrm{~km})$ glacier in North America (Molnia, 2008, p. K203); its accumulation zone includes the Bagley Ice Valley and Columbus Glacier. During a surge, Bering Glacier advances into and over a series of proglacial lakes very close to the Gulf of Alaska (Post, 1960, 1972; Molnia and Post, 1995a; Herzfeld, 1998; Molnia, 2001). As a result of the advance, the surge affects the ecological balance in the environment surrounding the glacier and potentially threatens shipping lanes through iceberg calving, so understanding the surge is important not only as a glaciological phenomenon, but also for the environment and society.

Bering Glacier last surged in 1993-95 (Post, 1972; Lingle and others, 1993; Molnia and Post, 1995, 2010b; Herzfeld and Mayer, 1997; Fatland and Lingle, 1998; Herzfeld, 1998; Mayer and Herzfeld, 2000; Molnia, 2001, 2008; Lingle and Fatland, 2003; Roush and others, 2003; Fleisher and others, 2010; Josberger and others, 2010; Shuchman and Josberger, 2010; Shuchman and others, 2010). The geography of Bering Glacier-Bagley Ice Valley, with place names, is described in Molnia and Post (2010a).

The current surge was preceded by a weak surge-type acceleration which started in 2008 and stopped in the same year. In 2009, no surge dynamics was observed, and in 2010 no observations were made (personal communication from B. Molnia, 2011). In early 2011, Bering Glacier's dynamics suddenly changed to that of a full-scale surge, with deformations and dynamics different than the previous surge. The surge started in lower central Bering Glacier on the northwestern side and soon reached the ice front in Tashalich arm (by May 2011). The 1993-95 surge started in a similar location (Herzfeld, 1998; Roush and others, 2003). The surge progressed up-glacier, as indicated by large, discrete crevasse fields separated by extensive regions of uncrevassed ice. By 25 September 2011, the surge had advanced into the Bagley Ice Field to $141^{\circ} 59^{\prime} \mathrm{W}$. Fresh enéchelon crevasse fields opened at several locations near the feet of topographic spurs that suggest subglacial morphologic induction (for an explanation, see Section 6). Judging by the clear-cut shapes of the crevasse fields, these must have opened only a few days before survey (Fig. 1). In 1994, surge crevassing had affected the entire Bering Glacier (Herzfeld, 1998), while in 2011 large parts of Bering Glacier continued to show ductile deformation typical of the quiescent phase, at a time when the surge kinematics had already progressed into the Bagley Ice Field.

\section{APPROACH: STRUCTURAL GLACIOLOGICAL PROVINCES}

An essential component of the crevasse classification is the observation that crevasses occur in large areas of similar crevasse patterns with clear boundaries to the neighboring areas of crevasses. This motivates use of the terminology of a 

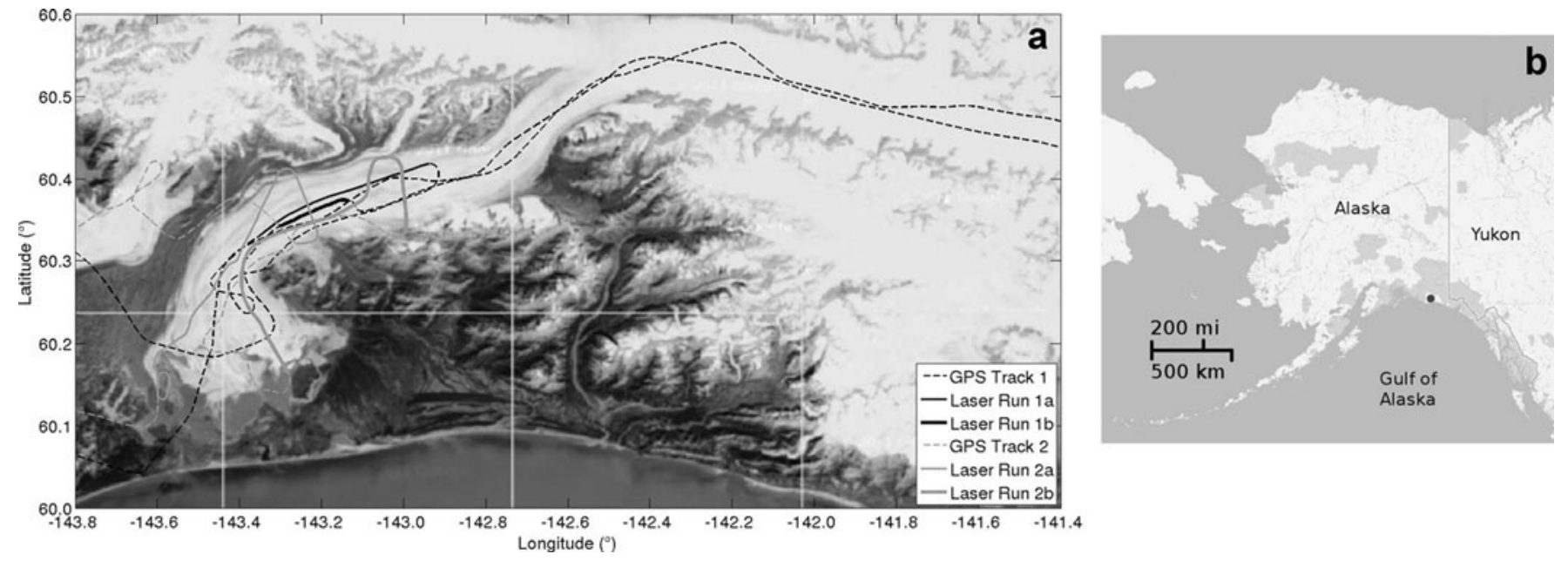

Fig. 2. Location and flight paths of data collection campaign over the Bering-Bagley glacier system, September 2011. (a) Bering Glacier is the glacier that calves into a series of proglacial lakes near $-143.5 \mathrm{E} / 60.15 \mathrm{~N}$, Steller Glacier is west of Bering Glacier, and Bagley Ice Valley is seen in the northern part of the map. Data collected over tracks marked 'GPS' are digital photographic data, digital video data and GPS data. Over tracks marked as laser runs, laser data were collected in addition to photographic, video and GPS data. Tracks indexed 1 were observed on 25 September 2011, and tracks indexed 2 on 26 September 2011. (b) Location of Bering Glacier, Alaska (terminal lobe marked by black dot).

structural province. A structural province is a region of a glacier that is homogeneous with respect to structural glaciological properties and that is maximal with this property. For instance, for a crevassed glacier, a structural province is an area that is maximal with the property of including the same crevasse type. The goal of the crevasse classification to be discussed in this paper is to utilize crevasse patterns derived from image data as a source of geophysical information. That this is conceptually possible is explained as follows.

The principal concept is that the dynamics of fast-moving ice manifest themselves in crevassing, so the deformation history of the ice can be reconstructed by analysis of crevasse patterns. Structural geological principles provide links between dynamics, kinematics and deformation, which can be physically formalized and quantified using continuum mechanics (Means, 1976; Suppe, 1985; Twiss and Moores, 1992; Ramsay and Lisle, 2000; Liu, 2002; Greve, 2003). Crevassing is a form of brittle deformation that occurs when local forces exceed a threshold. Characterization of generalized spatial surface roughness is a mathematical approach that utilizes parameters derived from spatial statistical functions to capture spatial properties of a surface (Herzfeld, 2008). This applies to crevassed and noncrevassed ice surfaces. Combining structural geology and mathematical roughness analysis allows the derivation of deformation characteristics in fast-moving glaciers, as described in theory in Herzfeld and others (2004), and the mapping of deformation provinces in surging and continuously fast-moving glaciers (Herzfeld and Mayer, 1997; Herzfeld, 1998; Herzfeld and others, 2000; Mayer and Herzfeld, 2000, 2001, 2008; Herzfeld and Zahner, 2001; cf. Vornberger and Whillans, 1990; Marmo and Wilson, 1998; Rist and others, 1999).

Hopkins (1862) gave an early explanation of crevasse patterns by applying stress analysis to the distribution of stress in a continuously deforming body. Mathematical description of the mechanical properties of glacier flow goes back to Nye (1952), who introduced the terms 'compressive flow' and 'extensive flow' and addressed the theoretical positions and directions of crevasses dependent on local stress fields (fig. 9 in Nye, 1952). Nye (1952) is concerned with the case of ductile deformation or continuous flow. Sudden changes in force typically accompany a surge and cause characteristic brittle deformation, which may be viewed as discretized flow or deformation events. The deformation events lead to fields of clear-cut crevasses. The different appearances of crevasse fields resulting from continuous deformation and discrete deformation are illustrated in a comparison of crevasse types of Jakobshavn Isbræ, Greenland, and Bering Glacier (Mayer and Herzfeld, 2000); mathematical differences are discussed in Herzfeld and others (2004).

\section{OBSERVATIONS}

Digital photographic data, digital video data, GPS data and laser altimeter data were collected over the Bering-Bagley glacier system during an aerial observation campaign in September 2011. Data were collected along pre-planned flight lines, which include lines that approximately follow the flowline and several lines that are perpendicular to the flowline (Fig. 2). The analysis presented here is based on airborne digital image data, referenced to position by GPS data of the plane's position. Although the pointing angle of the camera is only known with the accuracy of a handheld camera and aircraft motion was not recorded (other than by the flight-track GPS coordinates), the concept of structural provinces and the large size of these provinces assists with correctly associating deformation types to location. Satellite data from Digital Globe (WorldView) and the Geodetic and Earth Observing Satellite (GEOS) are also available, but there are no data that provide complete coverage of the glacier system at any point in time during the surge in 2011. For example, for a composition of WorldView imagery covering the entire Bering Glacier and Bagley Ice Valley, six images are needed and a set includes data from several different months. In comparison, the video and photographic image data collected during a single observation flight provide images of the glacier from the calving front to the upper Bagley Ice Valley all from the same day. 


\section{APPROACH: CONNECTIONIST-GEOSTATISTICAL CLASSIFICATION OF SURGE-CREVASSE IMAGES TO IDENTIFY STRUCTURAL PROVINCES}

\subsection{Overview}

The connectionist-geostatistical classification method was developed as a means to utilize imagery as geophysical data and analyze it to understand ice dynamics, motivated by the fact that during the last surge of Bering Glacier in 1993-95 only few geophysical data had been collected, but large amounts of video and photographic imagery recorded. The concepts of structural glaciology, as briefly introduced in Section 3, provide the theoretical link.

The classification method builds on concepts from signal processing, geostatistical data analysis and neural networks (Herzfeld, 2008). In the form that will be used in the analysis of 2011 surge data, the method proceeds by calculating spatial structure functions - here, generalized vario functions - from image data (using the whole image for video scenes, a significant subset for photographs and a moving window for satellite imagery) and extracting discretizations of several directional functions. The discretization of directional vario functions determines the activation of the input nodes in a neural network (input matrices). Alternatively, parameters extracted from the functions can be composed into feature vectors, on which the classification is built. Association of input matrices to crevasse classes, and hence deformation types, by a connectionist algorithm is correct in $95 \%$ of all cases for crevasse images in a validation set (i.e. images that were not used in the training step of the neural net) (Herzfeld and Zahner, 2001; Herzfeld, 2002).

Application of the connectionist-geostatistical method to imagery from flight tracks covering the entire glacier system will allow the creation of a segmentation of the glacier into deformation provinces, at a single point in time. The segmentation can be turned into an automatically derived map of the deformation state at that time point. Time series formed from several such maps will allow mapping of the surge progression.

\subsection{Neural networks and vario functions}

An automated algorithm for association of imagery of surge crevasses to deformation types needs to (a) capture the salient information in each image, (b) reduce the total data volume, so that the algorithm is computationally affordable, and (c) perform class association correctly in most cases. The concept of connectionism builds on the idea that associations that can be performed by the human brain can also be approximately performed by an automated algorithm. De facto, neural networks are comparable to complex mathematical optimization algorithms, that are trained in a supervised step (Herzfeld and Zahner, 2001). For a general introduction to neural nets, the reader is referred to Bishop (1995); neural networks used for pattern recognition are covered by Ripley (1996) and Looney (1997). Useful information may also be found on the World Wide Web.

The concept of connectionism suggests the primary idea of training a neural net on images of crevassed surfaces. However, this is computationally prohibitively expensive, especially with today's high-resolution cameras. Using only small subsets of images does not capture the spatial structure of crevasses. Therefore, vario functions are employed to accomplish requirements (a) and (b). The vario function takes the role of an information filter that retains spatial characteristics at that intermediate scale that includes crevasse spacing, directions and other generalized roughness properties. As the type of the neural net, we use a multilayer feed-forward perceptron with back-propagation of error (MLP-BP).

\subsection{Definition and calculation of vario functions}

Conceptually, the vario function is inspired by the variogram used in geostatistics in a probabilistic framework, but defined in a discrete mathematics framework that facilitates numerical implementation and generalization to higher order (important for noise reduction) (Herzfeld, 2002). Here we use the residual first-order vario function, defined as

$$
v_{1}(h)=\frac{1}{2 n} \sum_{i=1}^{n}\left[z\left(x_{i}\right)-z\left(x_{i}+h\right)\right]^{2}
$$

for pairs of points $\left(x_{i}, z\left(x_{i}\right)\right),\left(x_{i}+h, z\left(x_{i}+h\right)\right) \in \mathcal{D}$, where $\mathcal{D}$ is a region in $\mathcal{R}^{2}$ (case of survey profiles) or $\mathcal{R}^{3}$ (case of survey areas) and $n$ is the number of pairs separated by $h$; the distance value $h$ is also termed 'lag'. The function $v_{1}(h)$ is called the first-order vario function. This function exists always and has a finite value, because only finitely many data points enter the calculation. In situations where a regional trend or a local drift underlies the data, the residual vario function is often more useful for analyzing roughness. Using

$$
m(h)=\frac{1}{n} \sum_{i=1}^{n}\left[z\left(x_{i}\right)-z\left(x_{i}+h\right)\right]
$$

the residual vario function is defined as

$$
\operatorname{res}_{1}(h)=v_{1}(h)-\frac{1}{2} m(h)^{2}
$$

To illustrate the relationship between vario functions and crevasse images, a global vario function (numerically equivalent to the global variogram; see Herzfeld, 2002) is given in Figure 3. The numerical implementation of the vario-function calculation makes use of the organization of pixels and uses several algorithms specially designed to retain spatial information while reducing computation time. In practice, we use residual vario functions, standardized to maximum value of 1 . Vario functions are calculated in several directions. The advantage of the vario function is that it is built on increment values, and hence absolute radiometric reference is not needed. In practice, the classification is not affected by the direction or intensity of lighting during image collection. To ascertain that flight direction and camera pointing does not affect the crevasse classification, directional vario functions are calculated. Furthermore, the algorithm is trained to ensure independence from rotation and translation. To identify the neural-net topology of the MPL-BP, pre-training using simplified and simulated crevasse patterns was undertaken. Further detailing of the numerical and computational aspects of the connectionistgeostatistical methods lies beyond the scope of this paper.

\section{CLASSES OF SURGE CREVASSES}

The following crevasse types are used as the basis of the classification: (0) undisturbed surface or snow surface, (1) chaos, (2) parallel crevasses, (4) acute-angle bidirectional crevasses, (5) bidirectional crevasses with one dominant direction, (6) square-top blocky crevasses, (7) rhombic crevasses, (8) en-échelon crevasses. Examples of these types as observed during September 2011 are shown in Figure 4. 

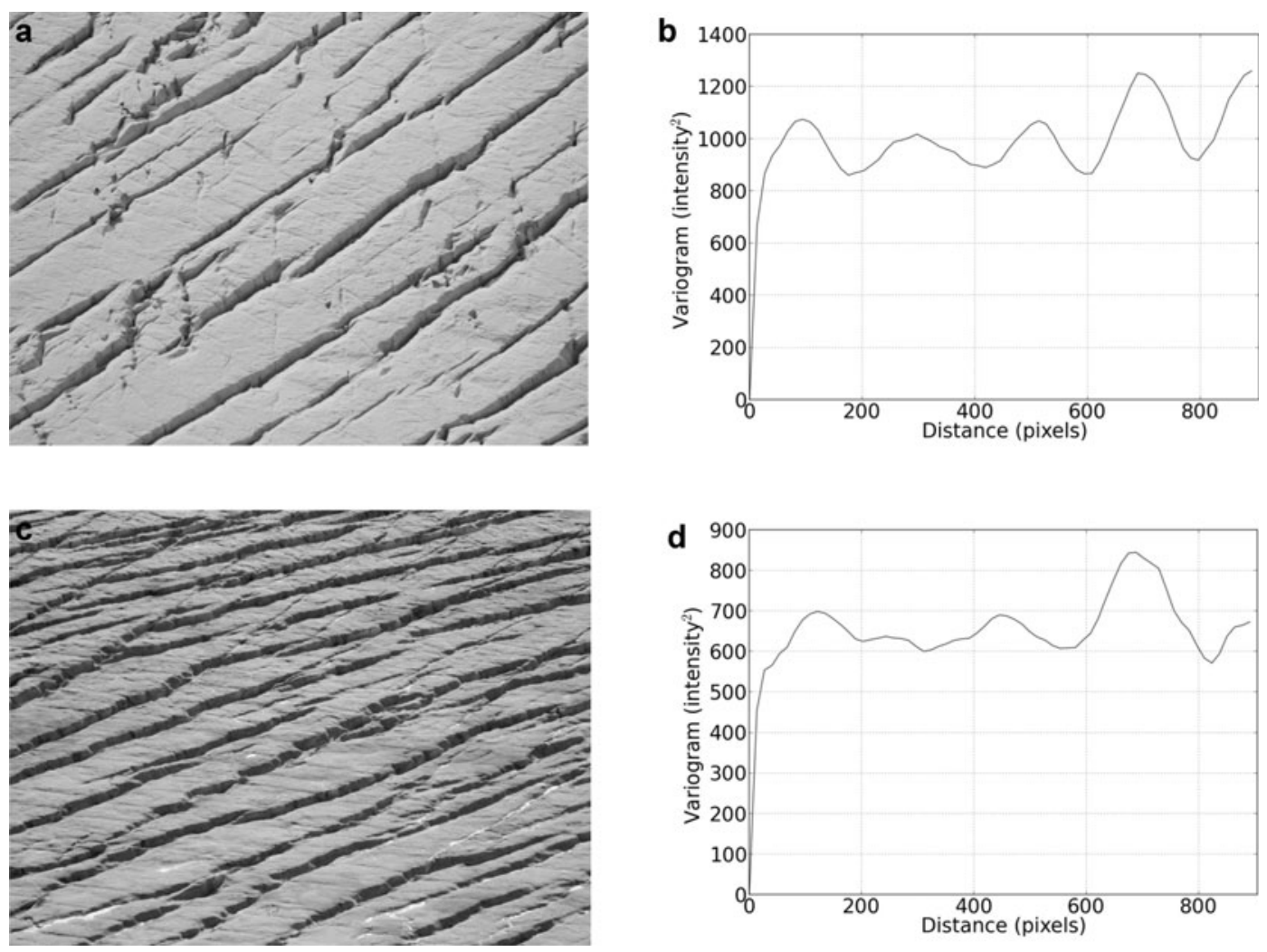

Fig. 3. Illustration of the relationship between crevasse-pattern images and vario functions. Here the global variogram is shown $((a, c)$ images; (b, d) variograms). The algorithm for the connectionist classification utilizes discretized four-directional residual vario functions.

Parallel crevasses (class 2) result from extension and form parallel to the direction of the extensional force. Parallel crevasses can also be caused by compression and then form in the direction normal to the direction of the acting force; however, extension prevails during a surge. Acute-angle bidirectional crevasses (class 4 ) form when one-directional extension is accompanied by a relatively small amount of shear. Bidirectional crevasses with one dominant direction (class 5) are caused by extensional forces acting in two directions, but with a much stronger force in one direction and a weaker force in the other direction. These usually form in two generations. Square-top blocky crevasses (class 6) form when two-dimensional extension occurs, where forces acting in two directions are equal and the directions of force are normal to each other. Square-top blocky crevasses are common signs of a surge and were observed at the start of the surge in 1993, but also at later stages. Rhombic crevasses (class 7) form under similar conditions to square-top blocky crevasses, but the directions of force are not normal. Enéchelon crevasses (class 8) form when a force breaks at preexisting weaknesses and indicate two different deformation events. A first deformation event leads to opening of a crevasse field, then a second, weaker kinematic event affects the crevasse field and causes feathery-appearing small crevasses along the edges of the first generation of crevasses. Depending on the size of the force, the feathery en-échelons may visually dominate the original crevasses. En-échelon crevasse fields are typically observed in Bagley Ice Field and indicate the progression of the kinematic wave associated with the surge into an area that previously has not been affected by the surge. The pre-existing crevasses are often found in extensions of topographic spurs which likely continue under the ice; the subglacial extensions cause crevassing. We call these morphologically induced crevasses. The kinematic force of the surge wave far from its origin near the collapsing reservoir may be too weak to cause crevassing in unbroken ice, but strong enough to cause en-échelon crevasse fields when it reaches an area of morphologically induced crevasses (Herzfeld and Mayer, 1997). The class 'chaos' (class 1 ) is associated with crevasse fields that have experienced several deformation events that cannot be reconstructed individually any more. Undisturbed surfaces or snow surfaces form the rest class of the crevasse classification. The classes are the same as used in the classification of the 1993-95 surge, except that class 3 (parallel crevasses filled with snow) was not observed and is left out in the neural net. From the input images, all possible rotations are created.

\section{TRAINING AND VALIDATION OF THE NEURAL NET}

The topology of the neural net is given in Figure 5. The neural net is first trained with simulated images showing simplified crevasse patterns. The learning curve is seen in Figure 6. Class association employs a simple winner-takes-all rule. Once the neural net training is completed, it needs to be validated using data not included in the training runs (Fig. 4).

\section{DISCUSSION AND OUTLOOK}

The connectionist-geostatistical method works well to derive deformation types from aerial image data. Because crevasse provinces have sizes on the order of several kilometers and are homogeneous with respect to deformation types, the association of deformation matrices to 


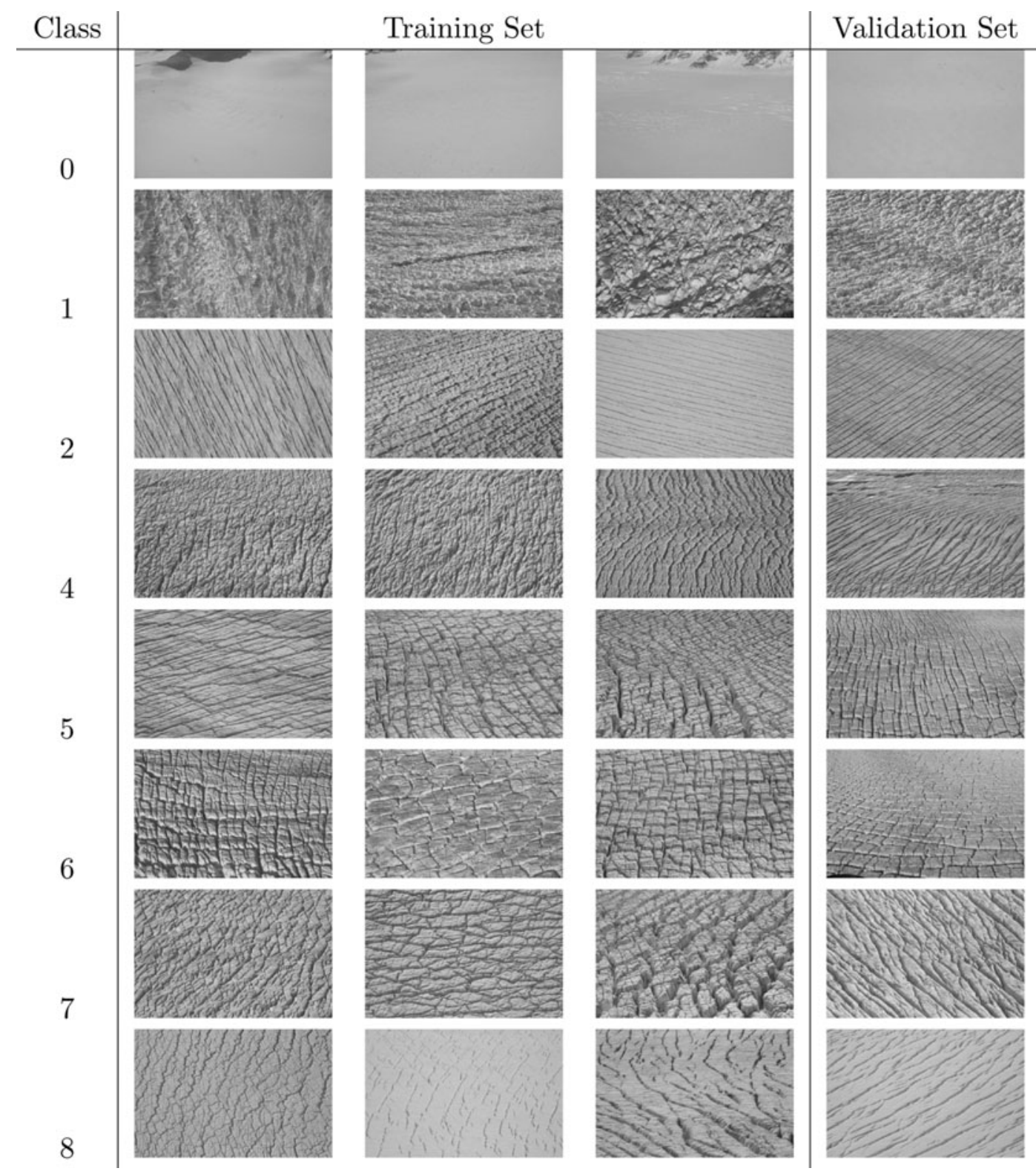

Fig. 4. Crevasse types of the Bering Glacier surge in 2011 used in connectionist-geostatistical classification. Images from September 2011.

locations on the glacier is correct, as can be evaluated using visual comparison with overview photographs.

Application of the connectionist-geostatistical method to imagery from flight tracks covering the entire glacier system will allow the creation of a segmentation of the glacier into deformation provinces, at a single point in time. The segmentation can be turned into an automatically derived map of the deformation state at that time point. Time series formed from several such maps will allow mapping of the surge progression.

However, limitations in position accuracy in the current analysis are due to (1) handheld operation of all cameras and (2) lack of recording of aircraft attitude. This complicates automatic processing of images, especially geolocation. In addition, contrary to expectation, time-coincident or neartime satellite imagery was only acquired for a small part (one-sixth) of the Bering-Bagley glacier system (satellite image data acquisition is controlled by an agency that is unrelated to this project, and while data can be acquired after collection, data acquisition strategies cannot currently be changed for science purposes). In aerial observations planned by our group for summer 2012, an integrated system with a nadir-pointing laser and a nadir-pointing camera will be used, together with a GPS system and an inertial measurement unit (IMU) recording aircraft position and attitude. More precisely, laser profilometer and video camera point in a direction normal to the aircraft, which corresponds to nadir for a level plane position. The integrated system will be operated through an opening in the aircraft bottom, which facilitates continuous operation during all flights. Resultant data will allow a significant reduction of the geolocation error in automated processing and hence improve the accuracy of automated segmentation of the glacier into structural provinces.

\section{SUMMARY}

The objective of this paper is to introduce an automated connectionist-geostatistical classification method as an approach to map deformation stages and surge progression. The approach is demonstrated for the current (2011) surge of the Bering Glacier and Bagley Ice Valley. 


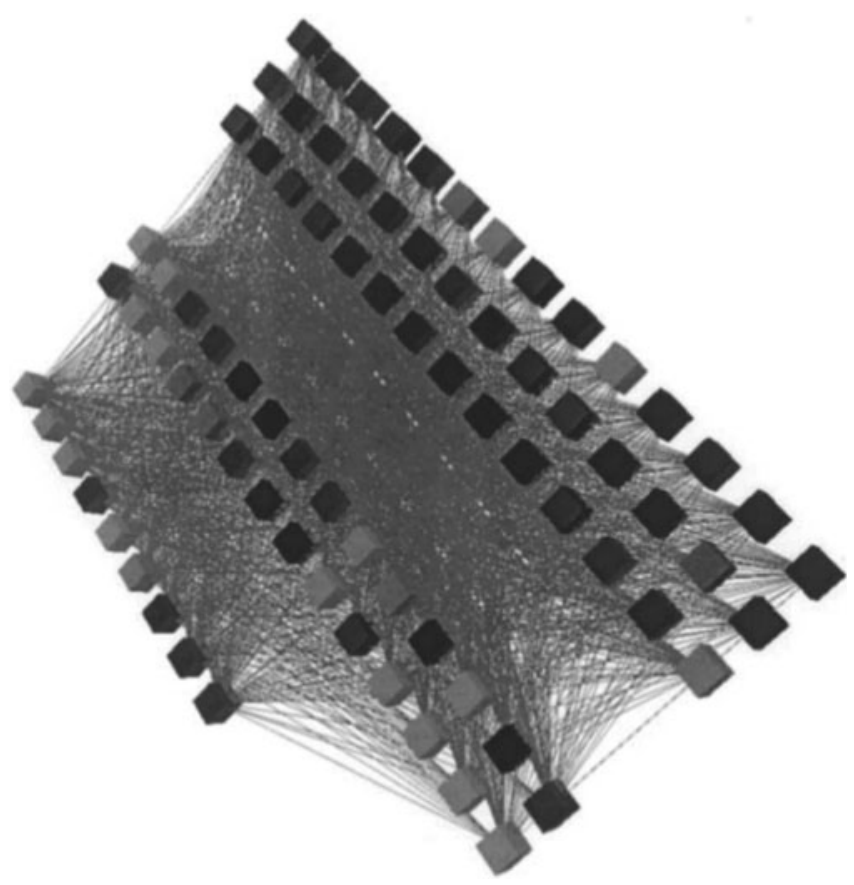

Fig. 5. Neural network used for crevasse classification.

The approach employs the concept of a structural province, which is an area that is maximal with respect to homogeneity of deformation, observed as crevassing. Images of crevasses serve as input data for the analysis. In the application to the current surge of the Bering-Bagley glacier system, aerial image data were collected from small aircraft in September 2011 and geolocated approximately using GPS data.

The classification method allows the use of imagery as geophysical data. To this extent, the method utilizes geostatistical vario functions as a means to capture relevant spatial information while reducing data volume, before a neural network is trained and applied for association of crevasse classes or deformation types to output from the vario-function calculation. In this paper, individual images are classified. Application to imagery that covers the entire Bering-Bagley glacier system will allow derivation of a thematic map of the glacier system that shows deformation types, and extension to several time-steps is expected to provide a systematic mapping as well as an objective quantification of surge progression in space and time.

\section{ACKNOWLEDGEMENTS}

This paper is dedicated to the memory of Austin Post who studied Bering Glacier during several of its previous surges and knew more about Alaskan surge glaciers than any other person in glaciological history. The first author was fortunate to share many good field days with Austin during 1993 and 1994 at Bering Glacier. Thanks are due to Bruce Molnia for alerting U.C.H. to the start of the surge in June 2011, to Maciej Stachura for help with field data collection in 2011, to our pilot Terry Kennedy, to Katie and Tom Prijatel of Alaska Wilderness Air, Cordova, to Oliver Zahner for discussion of the 1993-95 classification and to Thomas Trantow for help with figure preparation. Support of the research presented here through the US National Science Foundation's Arctic Natural Research Program under award

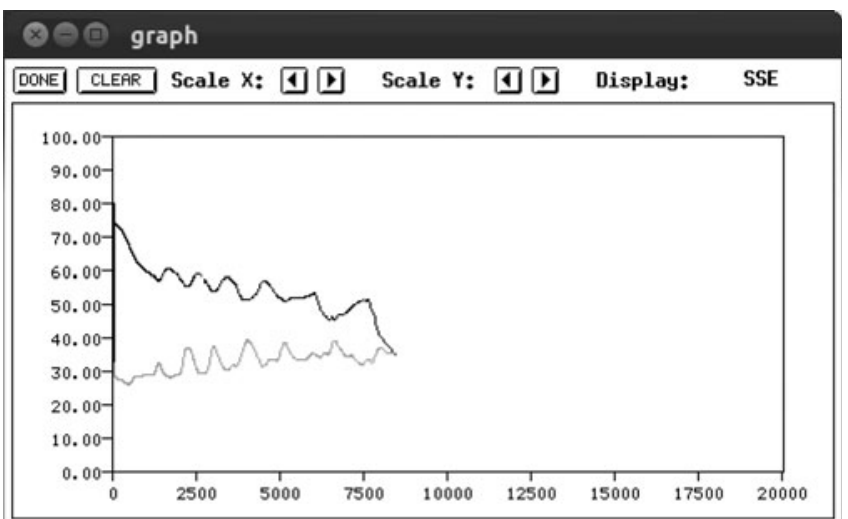

Fig. 6. Training curve for neural net (simulated crevasse images). The training set (black line) error ( $y$-axis) decreases as the number of training cycles ( $x$-axis) increases. The validation-set (grey line) error remains fairly constant with continued training. A network is trained when minimal error is reached.

ARC-1148800 and Research Experience for Undergraduates (award ARC-1247839) is gratefully acknowledged, the latter especially by the junior co-author, A.W. Support through the University of Colorado Undergraduate Research Opportunity Program is equally appreciated.

\section{REFERENCES}

Bishop CM (1995) Neural networks for pattern recognition. Oxford University Press, Oxford

Björnsson H, Pálsson F, Sigurðsson O and Flowers GE (2003) Surges of glaciers in Iceland. Ann. Glaciol., 36, 82-90 (doi: 10.3189/ 172756403781816365)

Bruhn RL, Forster RR, Ford ALJ, Pavlis TL and Vorkink M (2010) Structural geology and glacier dynamics, Bering and Steller Glaciers, Alaska. In Shuchman RA and Josberger EG eds. Bering Glacier: interdisciplinary studies of Earth's largest temperate surging glacier. (Special Paper 462) Geological Society of America, Boulder, CO, 217-234

Clarke GKC (1987) Fast glacier flow: ice streams, surging and tidewater glaciers. J. Geophys. Res., 92(B9), 8835-8841

Clarke GKC, Collins SG and Thompson DE (1984) Flow, thermal structure, and subglacial conditions of a surge-type glacier. Can. J. Earth Sci., 21(2), 232-240

Copland L, Sharp MJ and Dowdeswell JA (2003) The distribution and flow characteristics of surge-type glaciers in the Canadian High Arctic. Ann. Glaciol., 36, 73-81 (doi: 10.3189/ 172756403781816301)

Fatland DR and Lingle CS (1998) Analysis of the 1993-95 Bering Glacier (Alaska) surge using differential SAR interferometry. J. Glaciol., 44(148), 532-546

Fatland DR, Lingle CS and Truffer M (2003) A surface motion survey of Black Rapids Glacier, Alaska, U.S.A. Ann. Glaciol., 36, 29-36 (doi: 10.3189/172756403781816095)

Fleisher PJ, Bailey PK, Natel EM, Muller EH, Cadwell DH and Russell A (2010) The 1993-1995 surge and foreland modification, Bering Glacier, Alaska. In Shuchman RA and Josberger EG eds. Bering Glacier: interdisciplinary studies of Earth's largest temperate surging glacier. (Special Paper 462)

Flowers GE and Clarke GKC (2000) An integrated modelling approach to understanding subglacial hydraulic release events. Ann. Glaciol., 31, 222-228 (doi: 10.3189/ 172756400781820471)

Flowers GE and Clarke GKC (2002a) A multicomponent coupled model of glacier hydrology: 1 . Theory and synthetic examples. J. Geophys. Res., 107(B11), 2287 (doi: 10.1029/2001JB001122) 
Flowers GE and Clarke GKC (2002b) A multicomponent coupled model of glacier hydrology: 2. Application to Trapridge Glacier, Yukon, Canada. J. Geophys. Res., 107(B11), 2288 (doi: 10.1029/ 2001JB001122)

Greve R (2003) Kontinuumsmechanik: ein Grundkurs für Ingenieure und Physiker. Springer, Berlin

Harrison WD and Post AS (2003) How much do we really know about glacier surging? Ann. Glaciol., 36, 1-6 (doi: 10.3189/ 172756403781816185)

Herzfeld UC (1998) The 1993-1995 surge of Bering Glacier (Alaska) - a photographic documentation of crevasse patterns and environmental changes. Trierer Geogr. Stud. 17.

Herzfeld UC (2002) Vario functions of higher order - definition and application to characterization of snow surface roughness. Comput. Geosci., 28(5), 641-660

Herzfeld UC (2008) Master of the obscure - automated geostatistical classification in presence of complex geophysical processes. Math. Geosci., 40(5), 587-618

Herzfeld UC and Mayer H (1997) Surge of Bering Glacier and Bagley Ice Field, Alaska: an update to August 1995 and an interpretation of brittle-deformation patterns. J. Glaciol., 43(145), 427-434

Herzfeld UC and Zahner O (2001) A connectionist-geostatistical approach to automated image classification, applied to the analysis of crevasse patterns in surging ice. Comput. Geosci., 27(5), 499-512

Herzfeld UC, Mayer H, Feller W and Mimler M (2000) Geostatistical analysis of glacier-roughness data. Ann. Glaciol., 30, 235-242 (doi: 10.3189/172756400781820769)

Herzfeld UC, Clarke GKC, Mayer H and Greve R (2004) Derivation of deformation characteristics in fast-moving glaciers. Comput. Geosci., 30(3), 291-302

Herzfeld UC, McDonald B, Stachura M, Griffin Hale R, Chen P and Trantow T (2013) Bering Glacier surge 2011: analysis of laser altimeter data. Ann. Glaciol., 63(54), 158-170 (doi: 10.3189/ 2013AoG63A348)

Hopkins W (1862) On the theory of the motion of glaciers. Phil. Trans. R. Soc. London, 152, 677-745

Humphrey N, Raymond C and Harrison W (1986) Discharges of turbid water during mini-surges of Variegated Glacier, Alaska, U.S.A. J. Glaciol., 32(111), 195-207

Jiskoot H, Murray T and Luckman A (2003) Surge potential and drainage-basin characteristics in East Greenland. Ann. Glaciol., 36, 142-148 (doi: 10.3189/172756403781816220)

Josberger EG, Shuchman RA, Meadows GA, Savage S and Payne J (2010) Hydrography and circulation of ice-marginal lakes at Bering Glacier, Alaska, USA. In Shuchman RA and Josberger EG eds. Bering Glacier: interdisciplinary studies of Earth's largest temperate surging glacier. (Special Paper 462) Geological Society of America, Boulder, CO, 67-81

Kamb B and 7 others (1985) Glacier surge mechanism: 1982-1983 surge of Variegated Glacier, Alaska. Science, 227(4686), 469-479

Lingle CS and Fatland DR (2003) Does englacial water storage drive temperate glacier surges? Ann. Glaciol., 36, 14-20 (doi: 10.3189/172756403781816464)

Lingle CS, Post A, Herzfeld UC, Molnia BF, Krimmel RM and Roush JJ (1993) Correspondence. Bering Glacier surge and icebergcalving mechanism at Vitus Lake, Alaska, U.S.A. J. Glaciol., 39(133), 722-727

Liu IS (2002) Continuum mechanics. Springer, Berlin

Looney C (1997) Pattern recognition using neural networks. Oxford University Press, Oxford

Marmo BA and Wilson CJL (1998) Strain localisation and incremental deformation within ice masses, Framnes Mountains, east Antarctica. J. Struct. Geol., 20(2-3), 149-162

Mayer H and Herzfeld UC (2000) Structural glaciology of the fastmoving Jakobshavn Isbræ, Greenland, compared to the surging Bering Glacier, Alaska, U.S.A. Ann. Glaciol., 30, 243-249 (doi: 10.3189/172756400781820543)
Mayer H and Herzfeld UC (2001) A structural segmentation, kinematic analysis and dynamic interpretation of Jakobshavns Isbræ, West Greenland. Z. Gletscherkd. Glazialgeol., 37(2), 107-123

Mayer H and Herzfeld UC (2008) The rapid retreat of Jakobshavns Isbræ, West Greenland: field observations of 2005 and structural analysis of its evolution. Natur. Resour. Res., 17(3), 167-179 (doi: 10.1007/s11053-008-9076-7)

Means WD (1976) Stress and strain: basic concepts of continuum mechanics for geologists. Springer, New York

Meier MF and Post A (1969) What are glacier surges? Can. J. Earth Sci., 6(4), 807-817

Molnia BF (2001) Glaciers of Alaska. Alaska Geogr., 28(2)

Molnia BF (2008) Glaciers of North America: glaciers of Alaska. In Williams RS, Jr and Ferrigno JG eds. Satellite image atlas of glaciers of the world. (USGS Professional Paper 1386-K) United States Geological Survey, Denver, CO

Molnia BF and Post A (1995) Holocene history of Bering Glacier, Alaska: a prelude to the 1993-1994 surge. Phys. Geogr., 16(2), $87-117$

Molnia BF and Post A (2010a) Introduction to the Bering Glacier System, Alaska/Canada: early observations and scientific investigations, and key geographic features. In Shuchman RA and Josberger EG eds. Bering Glacier: interdisciplinary studies of Earth's largest temperate surging glacier. (Special Paper 462) Geological Society of America, Boulder, CO, 13-42

Molnia BF and Post A (2010b) Surges of the Bering Glacier. In Shuchman RA and Josberger EG eds. Bering Glacier: interdisciplinary studies of Earth's largest temperate surging glacier. (Special Paper 462) Geological Society of America, Boulder, CO, 291-314

Murray T, Luckman A, Strozzi T and Nuttall A-M (2003) The initiation of glacier surging at Fridtjovbreen, Svalbard. Ann. Glaciol., 36, 110-116 (doi: 10.3189/172756403781816275)

Nye JF (1952) The mechanics of glacier flow. J. Glaciol., 2(12), 82-93

Post AS (1960) The exceptional advances of the Muldrow, Black Rapids, and Susitna Glaciers. J. Geophys. Res., 65(11), 3703-3712

Post A (1972) Periodic surge origin of folded medial moraines on Bering piedmont glacier, Alaska. J. Glaciol., 11(62), 219-226

Ramsay JG and Lisle RJ (2000) The techniques of modern structural geology. (Applications of Continuum Mechanics in Structural Geology 3) Academic Press, London

Raymond CF (1987) How do glaciers surge? A review. J. Geophys. Res., 92(B9), 9121-9134

Ripley B (1996) Pattern recognition and neural networks. Cambridge University Press, Cambridge

Rist MA and 6 others (1999) Experimental and theoretical fracture mechanics applied to Antarctic ice fracture and surface crevassing. J. Geophys. Res., 104(B2), 2973-2987

Roush JJ, Lingle CS, Guritz RM, Fatland DR and Voronina VA (2003) Surge-front propagation and velocities during the early1993-95 surge of Bering Glacier, Alaska, U.S.A., from sequential SAR imagery. Ann. Glaciol., 36, 37-44 (doi: 10.3189/ 172756403781816266)

Shuchman RA and Josberger EG (2010) Bering Glacier: interdisciplinary studies of Earth's largest temperate surging glacier. (Special Paper 462) Geological Society of America, Boulder, CO

Shuchman RA, Josberger EG, Jenkins LK, Payne JF, Hatt CR and Spaete L (2010) In Shuchman RA and Josberger EG eds. Bering Glacier: interdisciplinary studies of Earth's largest temperate surging glacier. (Special Paper 462) Geological Society of America, Boulder, CO, 43-65

Suppe J (1985) Principles of structural geology. Prentice Hall, Englewood Cliffs, NJ

Twiss RJ and Moores EM (1992) Structural geology. W.H. Freeman and Company, New York

Vornberger PL and Whillans IM (1990) Crevasse deformation and examples from Ice Stream B, Antarctica. J. Glaciol., 36(122), $3-10$ 